\title{
Operational and design aspects of spears and scoop net used in Wular and Dal Lake of Kashmir, India
}

NIMAT SYED AND ASHISH S. MOHITE

Received : 26.05.2016; Revised : 18.08.2016; Accepted : 04.09.2016

See end of the Paper for authors' affiliation

Correspondence to :

\section{NIMAT SYED}

Department of Fisheries

Engineering, College of

Fisheries, Shirgaon,

RATNAGIRI (M.S.) INDIA

Email : nimatsyed11@

gmail.com
-ABSTRACT : Wular and Dal Lake are the two largest lakes of Kashmir contributing 70 per cent to the total fish landings of the state. The major catch from these lakes comprised of Cyprinus spp. which is exotic and Schizothorax spp. being the endemic to the lakes. During the study carried out on the operational and design aspects of scoop net and spears in Wular Lake and Dal Lake it was found that spear and scoop net were used in both the lakes. Two types of spears were used across Wular and Dal Lake i.e. multiple head spear, locally called as Panzri and double pronged spear, locally called as Narchoo. Scoop net, locally called as Khashiv and Kranz zal, was usually operated as a secondary gear.

KEY WORDS : Multiple head spear, Double pronged spear, Scoop net

- HOW TO CITE THIS PAPER : Syed, Nimat and Mohite, Ashish S. (2016). Operational and design aspects of spears and scoop net used in Wular and Dal Lake of Kashmir, India. Internat. J. Agric. Engg., 9(2) : 140-144, DOI: 10.15740/HAS/IJAE/9.2/140-144. 